\title{
CHOSEN SOCIOLINGUISTIC COMPETENCIES IN STUDENTS IN SECONDARY SCHOOL
}

\author{
Gregor Vnucko - Eva Reid
}

doi: 10.18355/PG.2022.11.1.3

\begin{abstract}
In this paper, we are concerned with one of the factors of intercultural communicative competence - sociolinguistic competence. First, we lay theoretical background for our research, explain the underlying methodology and after conducting the research, we analyse the data. Because we acquired the data from three different sources of the same information, we also explained the relations among them. Our research sample are students from 2.A from Golianove Gymnázium in Nitra and their teachers. This is a class which has more English lessons than usual and a native teacher. We created semi-structured interviews, based on two documents: The Council of Europe's CEFR (2001) and Reid's “Communicative competence connected with culture” (In Reid, 2014: 64). In our research results, we learnt that the students have very good socio-linguistic competence as they identified several examples to each of the chosen categories (greetings, titles and addressing, accents and dialects and colloquialisms, slangs and dialectisms). Every student interviewee also uses different multimedia on daily basis and the majority students state, that they consider being the main source of their socio-linguistic competence the multimedia. However, even though the relations between the specific phrases were not found within some categories (slang words and colloquialisms), teachers claim to have implemented activities that focus on these categories of socio-linguistic competence. To precisely identify the source of the students' socio-linguistic competence, further research would be necessary.
\end{abstract}

\section{Key words}

culture, communication, intercultural communicative competence, sociolinguistic competencies, interview, observation

\section{Introduction}

With the ongoing rapid advancement in communication technologies, we see an ever-increasing demand for making intercultural connections. Although knowledge of the language is important, there are many other factors which must be considered when engaging in intercultural interaction, some even hidden at first sight. It is important the students at schools are not only taught the raw language knowledge but are also exposed to activities which develop the more hidden parts of intercultural communicative competence. One of such examples are the sociolinguistic competences which, were the main focus of our research. In this first chapter of the paper, we will focus on laying background for research by explaining the underlying terminology. 
Culture is an important factor of intercultural communication. The origin of the word is found in Latin 'cultura' or 'cultus', meaning cultivation of soil or farming. Looking back to history, first use of this word can be tracked back to the $17^{\text {th }}$ century to name everything created by man. Following this trend, English anthropologist Edward B. Tylor used its English equivalent the first time when he published his major work "Primitive Culture" in 1871 (Prucha, 2010). There he (ibid.: 16) denoted culture as a "complex unit, which includes knowledge, religion. Art, law, morals, traditions and all other skills and customs, which person adopted as a member of a society". The definition, however, may vary from category, context, and scientific area. Jelenova (2014) suggests, that there can be as many definitions as there are scholars, researchers, and scientists concerned with its studies. Kroeber and Kluckhohn (1952) tried to somehow gather at that time all the known definitions of culture and created a summary, where they explained more than 160 of them. Since then, this number has grown even larger (Jelenova, 2014). Most of the authors (Hofstede, 2001; Matsumoto and Juang, 2015; Ting-Toomey, 1999) agree, that culture is unstable and possesses a changing character. Within every culture, there is some system of psychological phenomena, which is then passed on from generation to generation in order to ensure the survival of the group (Matsumoto and Juang, 2003). The psychological phenomena can be people's values, attitudes, behavioral patterns or beliefs and norms and the extent and specificity of these phenomena distinguish the units' culture which are then further projected into their daily artefacts (ibid.).

One could say, that among all other human traits the ability to transmit meaning from one person to the other is arguably the most important one. It effects not only our private life, but it has been interfering with our professional life and educational life for as long as we can remember (De Vito, 2001). The word communication comes from the Latin word 'communicare', and it means to share or to discuss something with someone. Communication begins in the moment, when from the informational source sender sends a message within a communication channel to the receiver. This process consists of 'ingredients of communication' (Samovar et al., 2015: 2829) or 'essential components of communication' (McLean, 2016: 13). Both authors agree that there are six important factors: source, message, channel, receiver, feedback, and interference (noise).

Intercultural communication, communication of people from different cultures, or even cross-cultural communication is as old as history itself, occurring in the form of wars or social exchanges (Balcescu, 2019). The formal study of 'intercultural', 'transcultural' or 'cross cultural' communication began in 1946, when Foreign Service Act started providing lingual and anthropological cultural training to diplomats (Jandt, 2017). The term Intercultural communication was first used by Hall (1959) within his book The Silent Language in 1959 (Neuliep, 2014). The process of communication can be labelled 'intercultural' when the sender of the message and the receiver come from different cultures. Samovar et al. (2015) suggest that "intercultural communication includes the interaction among people whose cultural perception and the system of symbols is different 
enough to alter the communication event". Arent (2009) adds, that intercultural communication does not necessarily have to be between people who speak a different language or living in a foreign country. For example, a 14-year-old teenager communicates in a different way than a senior raised in the same street or the same suburbia.

Samovar et al. (2015) pointed out that it is a common misconception that people are born effective communicators and so it is very important to develop cultural competence through the process of learning. To develop and improve the learner's language competence is the one of the aims of the FLT process. They are the sum of knowledge, skills and characteristics that allow a person to perform actions.

The Council of Europe (2001) in their document 'The Common European Framework Reference for Languages' provided a guideline and a syllabus for FLT as well as SLT and was translated for over 40 countries. It defines the learner's language competence and derives it into six levels from beginner to a proficient user. The CEFR is well known and respected among the foreign language teachers. For example, Hessova (2016:26) utilized the document as a guidance to creating her course "The Crosscurricular topic Multicultural Education in English classes", where she also focused on promoting cultural aspects, including the intercultural communicative competence. Other researchers (e.g., Paulikova, 2021; Reid, 2014) also used it in designing their research structure. The CEFR defines two main areas of the learner's competence: general competence and communicative competence. For the purposes of our research, we are mainly concerned with the communicative competences required in the intercultural interaction.

Even though these factors are very important in an effective communication and should not be neglected during school's English lessons, Reid (2014) in her research via the method of observation found out, that in Slovakia's primary schools, only $18 \%$ of teachers included cultural aspects within the English lessons. Based on the CEFR document (2001), Paulikova (2021) in their study also concerned themselves whether aspects of communicative competences were present in the Slovak and international textbooks for English lessons, and what were the teachers' attitudes towards implementing activities which promote such competences. The author (ibid.) declared that only one out of three analysed textbooks for English language instruction was in accordance with the CEFR (2001) requirements within the context of development of communicative competences.

Byram (1997: 71) defines intercultural communication competence as the ability "to interact with people from another country and culture in a foreign language. Their knowledge of another language is linked to their language competence to use language appropriately". A person possessing such competence can interact with other people effectively as well as be a mediator between people of different cultural backgrounds. He (ibid.) further distinguishes four components of ICC: linguistic, sociolinguistic, pragmatic, and intercultural competences.

The second component of communicative competence, as stated by Byram (1997) and The Council of Europe (2001), are sociolinguistic 
competences. According to Hymes (1972), for a learner to master a foreign language, one must be also competent in sociolinguistic competences, which he also perceives as a base for communicative language learning. Sociolinguistic competences deal with the aspects of language that are closely connected to the sociocultural aspect of a language. It further explains the linguistic markers of social relations; politeness conventions; expressions of folk-wisdom; register differences; and dialect and accent (Council of Europe, 2001).

These aspects of language are very often neglected during the process of FLT and are often assigned of lower importance in comparison to linguistic and pragmatic aspects of intercultural communication. (Reid, 2014). This is also in accordance with Paulikova's research (2021), where she found that even though the teachers considered sociolinguistic competences important, half of them admitted not to use practical activities to intentionally support the development of the competences, which was also mirrored in the observation, where only few lessons included such activities.

As we can see, there is multiple instances of neglecting the sociolinguistic competences within the lessons of English language. Based on CEFR's two documents: The Council of Europe's CEFR (2001) and Reid's "Communicative competences connected with culture" (In Reid, 2014: 64), we created several categories in which we identified sociolinguistic competence for our research: greetings, titles and addressing, accents and dialects and colloquialisms, slangs and dialectisms.

\section{Research aims and research questions}

The main research aim is to identify, analyse and explain what sociolinguistic factors of intercultural communicative competence are possessed by a group of students at a grammar school in Nitra.

Further research aims:

- To identify the chosen students' socio-linguistic competences.

- To identify and analyse the sources of the chosen students' sociolinguistic competences, whether they were acquired at school or from other sources.

- To identify teachers' attitudes and approaches towards developing sociolinguistic competences.

- To identify and analyse correlation between the education input and the chosen students' socio-linguistic competences.

\section{Research questions}

1. Which socio-linguistic competences have been developed by the students?

2. What was the students' attitude towards socio-linguistic factors of English? 
3. What was the teachers' input at school in developing the chosen socio-linguistic competences?

4. What was the teachers' attitude towards developing the chosen socio-linguistic competences during their English lessons?

5. From what other sources have the students developed their sociolinguistic competence?

\section{$3 \quad$ Research design and methodology}

The structure of our research was created mainly based on two documents: The Council of Europe's CEFR (2001) and Reid's "Communicative competences connected with culture" (In Reid, 2014: 64). In this research, we mainly aimed to identify one of the factors of intercultural communicative competence - the socio-linguistic competence possessed by the students from 2.A from Golianove Gymnázium in Nitra. To increase the reliability and verify our research, we collected the same data from three different sources. First, we interviewed the students on their sociolinguistic competence, then we interviewed teachers on the same subject and thus whether they had been implementing activities to develop such competences in their English lessons. Lastly, by using the method of observation as-participant we further verified the truthfulness of the data collected. For the purposes of this research, we have chosen qualitative research methods, namely method of interview and observation.

Based on the two documents mentioned at the beginning of this chapter, we created two semi-structured interviews with 13 main questions. The first type of interview focused to analyse the student's sociolinguistic competence within the following categories: greetings, titles and honorifics, accents and dialects, and slangs and dialectisms. For teachers and based on the interview with students, we again created a semi-structured interview with the same number of questions, however, in addition to their attitudes and approaches, we were also interested in what activities they implemented during their English lessons to develop socio-linguistic competences.

The reliability of the data collected was supported by using the method of triangulation, interviewing two different groups of participants (students and teachers) on the same chosen categories, and adding the method of observation further proved the truthfulness of the data. The interviewer strived to establish a friendly atmosphere and tried to stay neutral, avoiding any strong opinions and expectations. Furthermore, the interviews with all the students were following the same structure, with closed questions, supplemented by questions which were open-ended which allowed the interviewees to express themselves and add more information on the subject. The same applied to the interviewed teachers - both were given the same opportunities to express themselves and the interview followed the same structure for both. The analysis of the data was carried out through the process of coding and categorising. After collecting the data, we searched for anything that we considered interesting or important and highlighted it. After that, we searched for the relations among the collected data and created categories according to what similarities were found among this information. 
Subsequently, we searched for relations among the codes (which had already been established), analysed and explained them. All the categories and codes can be found in the appendices (appendix C).

Observation was chosen as a supplementary method to increase the reliability and validity of the research as well as a reality-check. We chose the observer as-participant method as we had already established codes from the data from the interview. Both the students and the teachers had been informed about our presence beforehand. The structure of the observation was created based on the codes and categories, which we had previously established by analysing the data from the semi-structured interview was the same for each lesson we observed. We were particularly interested in the occurrence of the phenomena established within these codes.

The first step to carry out our research in Golianove Gymnázium in Nitra, was to gain consent from the teachers to become the part of the research, which has been granted us via online video conversation. The next step was to gain consent of the students and because they were not yet adults, also a written consent from their parents or guardians was added. Finally, we asked for the permission the Gymnasium's headteacher by sending her a written form of consent by e-mail. Only after all these steps were completed, we could start our research. The participation on the research was voluntary, with a possibility to withdraw at any time. The names of the participants are confidential. We also needed consents from the headmaster, the student sample's teachers and the student's parents or guardians. After acquiring all the necessary consents and with regards to the ongoing social restrictions set by the Slovak government due to the COVID-19 pandemic, via a socialnetworking platforms we arranged meetings where the interviews were to be conducted. We chose this classroom randomly, but we found it very suitable for this research due to their overall high language competence as described in the following paragraph.

The research sample consisted of randomly chosen students from 2.A in Golianove Gymnazium in Nitra and their English teachers. 10 students participated in the research, in the age of 16 and 17 years. Their coursebook level was B2+ and three of them also attended a language school or an English tutorage at least two lessons a week. All the students have been learning English since elementary school and were eager to learn more about the language. One of the students also had an experience of using English abroad in Denmark, while visiting her family for a summer. The sample's overall language competence was very high. The teachers also had a very strong cultural background. To distinguish between them, we will refer to them as teacher participant no.1 and teacher participant no. 2. Teacher participant no. 1 has been teaching English in Slovakia for 20 years and has had experience of living abroad, in Manchester for a year. She had a master's degree in pedagogy of a joint degree of teaching English language and literature and teaching culture and art. Teacher participant no. 2 was a native lector from London, with a bachelor's degree in English literature with PGCE teacher qualification. He had taught also in other European countries before but spent most of his time here, in Slovakia where he had been already teaching English for 10 years. 


\section{$4 \quad$ Research analyses}

After explaining the underlying methodology in the previous chapter, this next chapter focus on clarifying the data we collected. The categories that had been established after the process of collecting the data, will be now further discussed. In each category, we will first describe the data collected from the student sample, then we will explain the data collected from the teachers and then we will conclude the category by explaining the results gathered by the method of observation. Further analyses of the research results will be provided in the discussion in the chapter 5 .

\section{Greetings}

In this first category, we were interested what different ways of saying ' $h i$ ' could the student interviewees think of, what greetings did the teachers include within their English lessons and what different greetings were actually present during the teachers' lessons. Based on their answers' formality and their usage, we divided the greetings into four codes: formal greetings upon arrival, formal greetings while leaving, informal greetings upon arrival, informal greetings while leaving.

To answer our question, all of the students could right away provide some formal greetings. All students mentioned 'Hi!', 'Hello!', 'Good morning!', 'Good afternoon!', 'Good evening!', 'Good night!'. Other formal greetings included: 'Good-bye!', 'Have a nice day!' and 'Greetings!'. In addition to formal greetings, all of the students provided at least one informal way which has not been mentioned before to say hi to a person in a different way. These included phrases such as: 'What's up?', 'How's it going?', 'Hey!', Howdy?', 'Long time no see!', 'How you doing?', 'See you!', 'Byebye!', 'Till next time!' and 'Talk to you later!'.

According to the teachers while carrying out the interviews with them, they both used different ways of saying hi during their lessons and also taught them. These phrases included: 'Good morning!', 'Good afternoon!', 'Good evening!', 'Good night!', 'Good-bye!', 'Have a nice day!', 'See you later, alligator!', 'What's up!', 'Hey!' and 'How you doing!'. However, according to the teacher interviewee no. 2, very often when he got a new class, he did an introductory lesson where he prepared at least 10 different ways of saying how are you with the students.

During the observation we identified many different greetings present in the teaching process. During the start of the lesson, formal greetings such as 'Good morning!', 'Good afternoon!' were used and also 'Hello!' and 'Hi!' by both the teachers and the students and at the end of the lesson 'Have a nice day!'. In one of the lessons, teacher asked the students whether they can still say 'Good morning!' or its already more appropriate 'Good afternoon!' (it was 11 a.m.). After that, the teacher explained that there is a difference on how we, Slovaks, use greetings according to time and how Englishmen use them. Also, in another lesson, teacher interviewee no. 2 checked attendance by asking the students how they were in different ways, 
also in informal varieties such as: 'How's it going?', 'What up?', 'What's up?' and 'What's up in the hood?'.

\section{Titles}

Next factor of sociolinguistic competence which we were identifying during our research, is how well and appropriately can students address other people and use titles. We achieved this by asking the student interviewees to name some titles which they use and also, we asked the teacher interviewees, what are their opinions on this topic and whether they include teaching different ways to address a person during their English lessons. All of the students showed confidence in addressing a person politely and each student interviewee also added at least one informal title used in colloquial English.

The first question at the start which we were interested in, is how the student interviewees address their teacher. All of the student participants claimed that they address their teacher as 'Mr. (Surname)' and 'Mrs. (Surname)'. According to the students, they have been asked to do so since their first lessons with the teachers. Other formal titles which could the students think of: 'sir', 'madam', 'lady', 'a gentleman'. Furthermore, they also added informal, affectionate phrases, usually the synonyms for the word friend, such as: 'mate', 'lad', 'buddy', 'bro', 'dawg', 'pal'; but also, other affectionate titles such as 'love' and 'honey'.

Next, during the interview with the teachers we asked them how the students address them, how they address their students and whether their give their students opportunities to be exposed to different titles in English throughout their English lessons. They recognized that in many schools, students address their English teachers as 'Mrs. teacher' or 'Mr. teacher' which is uncommon in English speaking countries. They claimed that they usually addressed their students by their first names or sometimes as ' $M r$. (Surname)' or 'Miss (Surname)'. Other titles which the teachers included in their lessons and could think of were 'mate', 'bud' and 'bro'.

What we have mentioned in the previous paragraph, also was confirmed in the observation that followed the interviews. The observation provided a reality check and indeed disclosed, that all of the students addressed their teachers and were addressed as it was described. Thus, the most frequent titles which occurred during the lesson were: 'Mrs. (Surname)', 'Mr. (Surname)' and 'ladies'. However, there were also some informal titles present, such as: 'guys', 'buddy', 'son' and (to a younger man).

\section{Accents and dialects}

In this next category, we were interested what different accents could recognise and what is their attitude towards different accents and dialects. After that, we interviewed the teachers and asked them whether they implemented such activities which will expose the students to different accents or dialects into their teaching process. The major accents or types of 
English the student interviewees mentioned and recognised were the US variety, the UK variety, Australian variety, and then various non-native accents such as Russian, Indian, Chinese, or African. We asked them to support some ideas in simple terms how they could describe the different accents or to mimic them if they agreed.

While interviewing the students on different accents, we found a lot of interest from their side. The students were familiar with different accents and most of them tried to get as close as possible to native-like accent. Generally, among the student interviewees, there was familiarity with American English and its varieties and referred to them as the variety easier to understand. On the other hand, strong accents in British English and its varieties were considered problematic for 9 out of 10 students, such as Scottish English, Irish English, and Welsh English.

During our interview, we asked the teachers whether they include teaching different accents and dialects in their English lessons. For the teacher interviewee no. 1, different accents were covered enough within the books which they followed. The opportunity to hear different accents was being provided by listening exercises. However, the interviewee also remarked, that the books usually do not state what is the origin of the speaker, so it is often difficult to determine what accent had the speaker in the listening exercise had. We also asked the teacher interviewee no. 2 how whether and how he exposes his students to different accents and dialects. The teacher interviewee no. 2 stated, that unlike the other non-native teachers at the school, he has the privilege for more "fun" lessons focused more on conversation. According to his opinion, his students had enough "traditional" listening activities during their other English lessons and thus focused more on the activities where he was imitating different accents himself and utilized his native experience. These included different varieties of British accents, American accents, and also non-native accents.

The major exposition of the accents the students had during the observation we carried out was their native teacher from London. Because his lessons mainly focused on conversation, the students were exposed to nativeEnglish throughout the whole lesson. Other than that, a listening exercise from an American TV show was provided for the students where the speakers spoke different varieties of American accents (African American and Californian accents). However, the accents were not discussed in any way with the students as it was not the main focus of the exercise.

\section{Colloquialisms, slangs and dialectisms}

During the interviews, we asked the student interviewees whether they can think of any words or phrases, which are characteristic for some region or country or general. Their answers included words and phrases, which were specific for one of the English varieties mentioned in the previous subchapter. The slangs and dialectisms stated by the students were: 'mate' (mainly $\mathrm{BrE}$ and $\mathrm{AuE})$, 'lad' (mainly $\mathrm{BrE}$ and $\mathrm{AmE})$, 'dawg' (mainly AmE), 'howdy?' (mainly AmE), 'bro' (mainly AmE), 'ma'am' (mainly 
AmE), 'Aussie' (AuE), 'barbie' (AuE), 'thongs' (AuE) and 'bickies' (BrE).

While carrying out the interview with the teachers, we asked them a question similar to the students', that being whether they include activities in their lessons which are primarily focused on the acquisition and recognition of English slangs and dialects. The words and phrases which the teachers used in their English lessons and could think of right away were: 'dawg', 'mate', 'son', 'buddy', 'love' and 'what's up'. Both of the teachers stated that they often emphasize the difference in some words within British English and American English and correct the students in case they used such word incorrectly.

During the observation, there was an authentic video activity of two elderly women. In this interview, they used slang words such as: 'selfie', 'twerking' and 'to cuss'. In other lessons, we were also able to identify some more extra slang words such as 'geek' and 'chillin'. Even though slang words and dialectisms were uttered during the observation, there was not any special activity which focused on the English slang and dialect words and phrases, but nonetheless the students had the opportunity to be exposed to them.

\section{Contact with English}

In this next category, we were interested what were the possible sources of the students' sociolinguistic competence, how they got in touch with English also outside the school and what do they thought was the primary source of their intercultural communicative competence.

In the first question, we asked the students whether they speaking to anyone in English outside the classroom and if so, how often. Eight students stated that they speak or chat to people outside the classroom in English, while five of them suggested that they do it on a daily basis. Mostly it was with friends from abroad, during online-gaming or even while talking to their Slovak friends through social media by using only English or partially using English.

All the student interviewees said that they came in contact with English also through multimedia on the daily basis. All of the asked students used social media and music to express themselves to English. Very popular sources of English among the asked students were also: Netflix (7 out of 10), YouTube (7 out of 10), Video games (6 out of 10) or English podcasts (4 out of 10). Other multimedia mentioned by the participants included: English television, news, and books.

According to 9 out of 10 asked student interviewees, the biggest impact on the development of their intercultural communicative competence were the sources outside of their traditional English lessons. From these, 6 out of 10 students considered different types of multimedia (Netflix, YouTube) to be the primary source of the aforementioned competence. Only one student considered to be her school the most important factor in developing her intercultural communicative competence as it motivated her to look for different sources for developing such competence. 
So far, we have only presented the data collected without much explaining the parallels among them. Because we did not have only one source and only one method of gathering the data from the sample, we still need to explain the data collected and to analyse the relations among them. This subchapter will serve for this purpose and for answering the research questions, which we have established in the chapter 2 of this paper.

The synonyms for the word hi, which were stated in the students' interviews, teachers' interviews and also occurred during the observations were following: Hi!', 'Hello!', 'Good morning!', 'Good afternoon!', Have a nice day!, 'What's up?', 'How's it going?'. As we can see, formal varieties prevailed in addition with very popular phrases, such as 'what's up?' and 'how's it going?'. The occurrence of the formal varieties can be assigned to the natural schools' formal environment, as these greetings are usually taught very early from the beginner levels. Other variations of the word ' $\mathrm{Hi}$ ', which were not mentioned neither in the teachers' interview nor occurred during the observation were following: 'Till next time!', 'Talk to you later!', 'Long time no see!' 'Hey!', Howdy?' and 'Greetings!'. Thus, this mixture of idioms, and slangs from southern American dialect ('Howdy?') could have been learned through other sources such as different kind of multimedia, which all of the students confessed to use on daily basis.

Very similarly to the previous paragraph, titles which we identified within all three data sources were: 'Mr. (Surname)', 'Mrs. (Surname)' and 'buddy'. We again assign this occurrence to the formality of the school's environment, and also to the fact, that the teachers asked the students to call them instead of 'Mr. teacher' as 'Mr. (Surname)'. We find this very plausible, as 'Mr. teacher' is a very common Slovak title, however not very common in English speaking countries. Other titles which were mentioned by the students during their interviews, however, did not occur during the lessons nor were said to be taught by the teachers were following: 'pal', 'love', 'honey', 'sir', 'madam', 'a gentleman', 'mate' and 'lad'. As we see, these are again informal and affectionate titles, very common in movies or TV series and could have been acquired through the source of multimedia.

Students could recognise and name many different native and nonnative accents: Australian accent, American accent, South American accent, British accent, English accent, Scottish English accent, Irish English accent, Welsh Accent, Chinese accent, Pakistani accent, and Russian accent. Because of the presence of the native speaker, the students had a first-hand experience in interacting with a teacher with a strong London accent. During the observation, we also identified an authentic video exercise, where there were three speakers: one with African American accent and two elderly ladies with Californian accent. However, no discussion about the speakers' accents took place during the lessons, thus the students were exposed to different varieties of American accents but may have not even realized it. 9 out of 10 students also stated, that they find strong British accents problematic, however, on the contrary only 1 out of 10 students stated the same about American accents. 6 out of 10 students considered American 
accents easier to understand and some even stated that "it is closer to how we speak". We thus assume, that during their use of multimedia they are majorly exposed to American accents, which leads to better listening comprehension which makes it seem for them that the American varieties of English are "easier".

Colloquialisms, slang words and dialectisms identified from the three different sources of data varied. Little concordance was identified between the phrases stated by the students and those stated during the interviews with the teachers or during observations. The colloquialisms, slang words and dialectisms which were identified only during the interviews with the students were following: 'lad' (mainly BrE and AmE), 'howdy?' (mainly AmE), 'bro' (mainly AmE), 'ma'am' (mainly AmE), 'Aussie' (AuE), 'barbie' (AuE), 'thongs' (AuE) and 'bickies' (BrE). Even though there were similar phrases present in the process of observations and the teachers stated to be teaching slang words and colloquialisms, we assume that these particular phrases have been taught by the students through some other sources of English, such as the multimedia.

As we can see there is no doubt that the students acquired a lot of socio-lingual competence through multimedia and sources of English other than lessons at their school. We were very surprised to hear, that the students even used English to talk to their Slovak peers in order to practise their English skills. However, we have to add, that the great development of the socio-lingual competence of those students is rather an exception than a rule, and our results cannot be generalised on all of the grammar school students because of the specifics of the sample.

We also identified great recognition of socio-linguistic factors during the interviews with the teachers, who claimed that they have been implanting activities to practice the aforementioned factors (greetings, titles, accents and dialects and colloquialisms slangs). Thus, to be able to precisely determine from which source have the students acquired their socio-linguistic competence, a much more extensive study with substantially a greater number of observations would be needed. This could be very difficult to achieve in practise, as many teachers may feel uneasy while being observed especially within such long periods of time.

\section{Answering the research questions}

\section{Which chosen socio-linguistic competences have been developed by the students?}

As we have already concluded in the previous subchapter, the students provided many examples to each of the categories. The students were able to provide us with different varieties of formal and informal greetings, of many formal and informal titles; recognised many different accents and could identify, which were problematic for them; and also showed competence in using slang words, colloquialisms and dialects. 


\section{What was the students' attitude towards socio-linguistic factors of English?}

Students during the interview showed curiosity and were interested in the sociolinguistic factors of English which may not be discussed so often as other language competences. With titles, when we asked the students for some informal, they replied that they have not had the opportunity to practise informal titles or address other people this way. After we finished the interview, students were curious about their answers, whether they were appropriate in the context or inappropriate. The interview itself felt very casual and beneficial for both sides. 7 out of 10 the students considered the major source of their socio-linguistic competence multimedia, 2 out of 10 it was language schools which they were attending and for the last student it was English lessons at their school.

\section{What was the teachers' input at school in developing the chosen socio-linguistic competences?}

There were instances of every factor of sociolinguistic competence present in the teachers' lessons. Because of the schools' formal environment, the titles and greetings chosen were usually formal, but we identified also instances when the teacher used different informal greetings and titles to address to students (while checking the attendance). There was also an authentic video activity for the students, which exposed the students to some many factors of socio-linguistic competence (informal titles, slang words).

4. What was the teachers' attitude towards developing socio-linguistic competence during their English lessons?

The teachers recognised the misunderstandings that could arise from negligence of socio-cultural competence straight away. First example which confirmed our opinion was, that unlike many other teachers, our teacher interviewees asked their students to address them as 'Mr. (Surname)' and 'Mrs. (Surname)'. In Slovakia it is very common that students call their teachers 'Mr. or Mrs. teacher', which is uncommon in English-speaking countries. They also showed curiosity while proceeding to the next questions of the interview but also recognised the importance of teaching idiomatic expressions. The native teacher was undoubtedly a great source of sociolinguistic competence for the students, as he consciously and subconsciously uses many idiomatic expressions, phrasal verbs, and slang words on daily basis and also during his English lessons.

\section{From what other sources have the students developed their socio- linguistic competence?}

Nowadays, student have all kinds of opportunities to be exposed to socio-linguistic elements in English. The students claimed to use different multimedia on daily basis, such as listening to music, watching Netflix and other streaming platforms, watching YouTube videos, English podcasts, English tv channels, news and reading books. 
In this paper, we were hoping to uncover not only the visible part of language, but also those parts which are at first subtle and often neglected during the teaching process (Reid, 2014). These also include the main topic of the research - the chosen socio-linguistic factors of intercultural communicative competence. We first established theoretical background for the reader to better understand the phenomena behind the research and established our main research objective. While laying out the theoretical background for our research, we chose to start from the most general terms and notions and slowly make our way to the most specific ones, which are the main topics of the research.

In the second chapter, we established the research aims, objectives, and the research questions. The main aim of this research was to identify, analyse and explain what selected socio-linguistic factors of intercultural communicative competence are possessed by a group of students at a grammar school in Nitra. We were also interested in the sources of these socio-linguistic competences as well as to the attitudes, which both the student groups and the teachers' groups had.

The procedure of the data gathering was explained in the third chapter. For the research, we collected data from three different sources with two different methods. First method was a semi-structured interview of the students and their teachers. Second method which we utilized was observeras participant, where we observed English lessons of the interviewed teachers to see the occurrence of the socio-linguistic elements first-hand. We created our own structures of the aforementioned methods mainly based on two documents: The Council of Europe's CEFR (2001) and Reid's "Communicative competences connected with culture" (In Reid, 2014: 64).

Within the analyses of the data collected, we found little consensus within the three sources of data. The biggest correlation was found in greetings ('Hi!', 'Hello!', 'Good morning!', 'Good afternoon!', Have a nice day!', 'What's up?', 'How's it going?'), titles ('Mr. (Surname)', 'Mrs. (Surname)', 'buddy') and accents (African-American accent, American accents, London accent). In these categories, we found that the teachers have had a great role in developing them. In the category of colloquialisms, the phrases provided from the three different sources did not match, even though the teachers claimed to have implemented exercises and activities in their lessons, which are focused specifically on this category.

Because the students stated that they used different types of multimedia on daily basis, the phrases which were not present during the observation nor during the interviews with the teachers may have been learned from this source. This includes informal titles ('pal', 'love', 'honey', 'sir', 'madam', 'a gentleman', 'mate', 'lad') and colloquialisms and slang words ('lad', 'howdy?', 'bro', 'ma'am', 'Aussie', 'barbie', 'thongs' and 'bickies').

To better understand what the source of the students' socio-linguistic competence was, a long-term observation of the English lessons would be necessary to confirm the occurrence of the socio-linguistic aspects in the 
teachers' lessons. We recommend the students to further improve themselves in their socio-linguistic competence and recommend the teachers to further include activities which develop such competence.

A huge part of the development of the student participants' sociolinguistic competence is the specifics of the sample, such as their teachers, their daily exposition to English via multimedia, and their enthusiasm in learning English. Even though it is rather an exception than a rule and our results cannot be generalised on all of the grammar school students, this research may have provided an insight into the parts of language which are very commonly overlooked during English lessons at schools and may have provided a model on what else can be included to the teachers' traditional lessons to better prepare their students to overcome obstacles, which may arise while using the language outside the classroom.

\section{Bibliographic references}

Arent, R. (2009). Bridging the Cross-Cultural Gap: Listening and Speaking Tasks for Developing Fluency in English. University of Michigan Press. ISBN 978047203 3577, pp. 1-17

Balcescu, N. (2019). The Intercultural Competence. Developing Effective Intercultural Communication Skills. International conference - The Knowledge-Based Organization 25(2). Doi: https://doi.org/10.2478/kbo2019-0092

Byram, M. (1997). Teaching and Assessing Intercultural Communicative

Competence. Philadelphia: Multilingual Matters. ISBN 185359377

COUNCIL OF EUROPE. (2001). Common European Framework of Reference for Languages: Learning, Teaching, Assessment. Cambridge University Press. ISBN: $9780 \quad 521$ 005319, Available online: http://www.coe.int/t/dg4/linguistic/Source/Framework_EN.pdf

Devito, A. J., (2001). The Interpersonal Communication Book. London: Longman. ISBN 9780321055644

Hall, T. E. (1959). The Silent Language. Doubleday, 1990. ISBN 978038505 5499

Hessova, L. (2016). The Newly Designed Course the Cross-Curricular Topic Multicultural Education in English Classes. Slavonic Pedagogical Studies Journal 5(2), pp. 217-231. ISSN: 1339-9055. Available online: http://pegasjournal.eu/files/Pegas2_2016_2.pdf

Hofstede, G. (2001). Culture's Consequences: Comparing Values, Behaviors, Institutions, and Organizations Across Nations. $2^{\text {nd }}$ edition. CA: Sage Publications. ISBN 9780803973244

Jandt, F. (2017). An introduction to intercultural communication: identities in a global community. $9^{\text {th }}$ edition. SAGE Publications. ISBN 9781506390727 Jelenova, I. (2014). Interkulturna Komunikacia. Univerzita Pavla Jozefa Safarika v Kosiciach. ISBN 9788081522253

Kroeber, A. L. \& Kluckhohn, C. (1952). Culture: a critical review of concepts and definitions. Cambridge

Matsumoto, D., \& Juang, L. (2003). Culture and psychology. $3^{\text {rd }}$ edition. Wadsworth: Cengage Learning. ISBN 9780534535919 
Matsumoto, D., \& Juang, L. (2015). Culture and psychology. $5^{\text {th }}$ edition. Wadsworth: Cengage Learning. ISBN 9781111344931

Mclean, S. (2005). The Basics of Interpersonal Communication. $6^{\text {th }}$ edition. Pearson. ISBN 978020540 1987, p. 10

Mclean, S. (2016). Business communication for success, Version 2.0. FlatWorld. ISBN 9781453374184

Neuliep, W. J. (2014). Intercultural communication. SAGE Publications. ISBN 9781452256597

Paulikova, K. (2021). Communicative Competence in English and its Development at the Primary Level of Education. Slavonic pedagogical Studies Journal 10(1), pp. 31-46. 2021. ISSN: 1339-9055. Available online: http://pegasjournal.eu/files/Pegas1_2021_3.pdf

Prucha, J. (2010). Interkulturni komunikace. Grada Publishing. ISBN 9788 024730691

Reid, E. 2014. Intercultural Aspects in Teaching English at Primary Schools. Frankfurt am Main: Peter Lang Publishing Group. ISBN 9783631655535

Samovar, L., Porter, R., Mcdaniel, E., \& Roy, C. (2015). Communication Between Cultures $9^{\text {th }}$ edition. Boston: Cengage learning. ISBN 978128544 4628

Ting-Toomey, S. (1999). Communicating Across Cultures. MI: Guilford Press.

Mgr. Gregor Vnucko

Department of English Language and Culture

Faculty of Education

Constantine the Philosopher University in Nitra

Drazovska 4, 949 74, Nitra

Slovakia

Gregor.vnucko@ukf.sk

doc. Mgr. Eva Reid, PhD.

Department of English Language and Culture

Faculty of Education

Constantine the Philosopher University in Nitra

Drazovska 4, 949 74, Nitra

Slovakia

Ereid@ukf.sk 


\section{Appendices}

\section{Appendix A: Interview on sociolinguistic competence for students}

\section{Greetings,addressing:}

1. Aké pozdravy poznáte $\mathrm{v}$ angličtine?

2. Ako oslovujete svojho učitel’a AJ? Aké iné oslovenia poznáte?

\section{Use of exclamations:}

3. Poznáte v angličtine nejaké zvolania ? Ak áno aké? (napr. Oh dear!)

a. Ako by ste použili takéto zvolanie vo vete?

b. Vedeli by ste $\mathrm{v}$ angličtine aj zahrešit?

\section{Positive/negative politeness (also 5b,6f,6g):}

4. Ako by ste sa opýtali nasledovnú otázku čo najslušnejším spôsobom:

a. V nóbl reštaurácií na formálnej večeri pri Vás sedí staršia pani a nedočiahnete na sol'ničku.

A: „Podajte mi sol!!“

\section{Impoliteness:}

5a. Znejú Vám nasledovné frázy ako slušné, neslušné alebo neutrálne:

-Get lost!

-Suit yourself!

-Be my guest!

-Who asked you?

b. Vedeli by ste vymenovat' aj viac podobných fráz?

Appropriate use of please/thank you/excuse me/I'm sorry:

6. Ako by ste preložili nasledovné frázy/vety do AJ bez toho, aby ste zmenili ich význam?

a. Kamarát kamarátovi.

A: Tu sú tie fotky.

B: Ďakujem

A: Prosím.

\section{b. Diet'a matke.}

A: Prosím mami ja sa chcem hrat!

c. Na hodine $v$ škole.

A: Mohol by som dnes odíst' o 5 minút skôr, prosím?

d. V reštaurácii :

A: Prosím si kávu s mliekom. 
e. V reštaurácií Vám obsluha položí na stôl kávu:

\section{A: Prosím!}

f. Vášho priatel’a neprijali na vysokú školu na ktorú chcel ist:

A: To mi je lúto.

g. V autobuse Vám stoja l’udia $v$ ceste a snažite sa pretlačit':

A: S dovolením!

e. Pristúpite k neznámemu človeku, chcete na seba upozornit' a spýtat'sa na čas:

A: Prepáčte, kol'ko je hodín?

\section{Proverbs/idioms}

6. a. Poznáte nejaké anglické príslovia, idiómy, frázy?

b. Dokázali by ste preložit nasledovné idiómy?

1. I'm feeling under the weather.

2. He is a fair-weather friend.

c. Dokázali by ste preložit’ nasledovné idiómy s použitím slova leg?

1. Zlom väz

2. Ut’ahuješ si zo mňa?

d. Dokázali by ste preložit' ešte niektoré z nasledovných idiómov?

1. Spomeň čerta!

2. Držím palce!

3. Zaklop si na drevo!

\section{Dialect/accent}

8. Máte nejaký oblúbený prízvuk ku ktorému sa snažíte priblížit? Robí Vám problém rozumiet' ak má niekto silný prízvuk?

\section{General}

9. Aké nárečové frázy alebo slangové slová v poznáte $\mathrm{v}$ angličtine?

10. Rozprávate sa s niekým po anglicky aj mimo školy? Ak áno s kým a ako často?

11. Stretávate sa s angličtinou prostredníctvom multimédií?

a. Streamovacie platformy (Netflix, YouTube, Disney plus..)

b. Video hry - ak áno tak aké

c. podcasty - aké

d. hudba

e. iné 
12. Navštevujete jazykovú školu alebo chodíte na doučovanie anglického jazyka?

13. Odkial' máte pocit že ste sa najviac zlepšili v angličtine?

\section{Appendix B: Interview on sociolinguistic competence for teachers}

\section{Greetings, addressing:}

1. Aké pozdravy učíte $\mathrm{v}$ angličtine? (formálne, neformálne, nárečové, slangové...)

2. Používate na hodinách AJ rôzne oslovenia? Aké d'alšie oslovenia učíte svojich žiakov? (Formálne, neformálne, nárečové, slangové..) Ako vás oslovujú na hodine? Prečo?

\section{Use of exclamations:}

3. Používate na svojich hodinách AJ nejaké zvolania? Ak áno aké? (príklad, Oh my god! Oh my gosh!)

Aj ich zahŕňate do vyučovania?

\section{Positive/negative politeness:}

4. venujete sa na hodinách positive/negative politeness? Slovné spojenia na vyjadrenie.

It's kind of cold in here. Could we close the window?

\section{Appropriate use of please/thank you:}

5. Učíte svojich žiakov rozdiel medzi slovenským a anglickým please/thank you? (rozdiely najmä)

Napr. veta: a: Tu máš tie fotky b: Ďakujem a: prosím

A: prosím si kávu s mliekom...

\section{Impoliteness}

6. Učíte svojich žiakov rozlišovat' medzi slušnými a neslušnými frázami? (napr. get lost! who asked you?, direct orders) - ako vyjadrit' nesúhlas, frustráciu, zlost' + používate niektoré na hodinách? Príklady?

\section{Proverbs/idioms}

7. Používate niekedy na svojich hodinách rôzne porekadlá alebo idiómy? Aj ich učíte žiakov?(ak si spomenú)

Môžete mi vymenovat' nejaké príklady?

\section{Dialect/accent}

9. S akými rôznymi prízvukmi sa stretávajú (majú možnost' sa stretnút') žiaci na Vašich hodinách AJ?

9b. Zoznamujete svojich žiakov s rôznymi prízvukmi/nárečiami? Rozdiely medzi BrE/AmE?

10. Učíte Vašich žiakov nárečové alebo slangové slová? Aké napr.?

11. Kol'ko učíte angličtinu?

12. Aké je vaše učitel'ské vzdelanie?

13. V ktorej časti Anglicka ste žili/pochádzate 


\begin{tabular}{|c|c|c|c|c|c|c|c|c|}
\hline \multicolumn{2}{|c|}{ Appendix } & \multicolumn{2}{|l|}{ C: } & \multicolumn{2}{|l|}{ Data } & in & \multicolumn{2}{|c|}{ excel } \\
\hline Code no. & Greetings & No. of students & Code no. & Titles & No. of students & Code no. & Expressing anger, frustra & Teachers \\
\hline \multirow[t]{5}{*}{1.} & Formal upon arrival & & 5. & Formal titles & & 8. & Religious & \\
\hline & Hi! & 10 & & Miss & 10 & & Oh my God! & 10 \\
\hline & Hello & 10 & & Mrs. & 10 & & Jesus Christ! & 4 \\
\hline & Good (morning, afternoon..)! & 10 & & Mr. & 10 & & Holy moly! & 1 \\
\hline & Greetings! & 2 & & Sir & 8 & & Damn! & 1 \\
\hline \multirow[t]{3}{*}{2.} & Formal while leaving & & & Madam & 6 & & What the hell? & 1 \\
\hline & Good-bye! & 4 & & Lady & 3 & & Bloody hell! & 1 \\
\hline & Have a (good..) day! & 3 & & Gentleman & 1 & 9. & Avoiding profanity & \\
\hline \multirow[t]{7}{*}{3.} & Informal upon arrival & & 6. & Informal neutral & & & Oh, shoot! & 1 \\
\hline & What's up? & 5 & & Guys & 3 & & Oh, freak! & 2 \\
\hline & How's (it goin')..? & 3 & 7. & Informal affectionate & & & Oh, gosh! & 2 \\
\hline & Hey! & 3 & & Mate & 5 & & Oh, fudge! & 1 \\
\hline & Howdy? & 2 & & Bro & 3 & & What the heck? & 2 \\
\hline & Long time no see! & 1 & & Buddy & 2 & & Oh, lord! & 1 \\
\hline & How you doin'? & 1 & & Lad & 2 & 11. & Mild expetives & \\
\hline \multirow[t]{17}{*}{4.} & Informal while leaving & & & Dawg & 2 & & Crap! & 1 \\
\hline & See you...! & 6 & & Honey & 2 & & Oh, shit! & 2 \\
\hline & Bye bye! & 6 & & Love & 1 & 12. & Strong expletives & \\
\hline & Till next time! & 1 & & $\mathrm{Pal}$ & 1 & & What the fuck! & 1 \\
\hline & Talk to you later! & 1 & & & & & Holy Fuck! & 1 \\
\hline & & & & & & & I don't give a fuck! & 1 \\
\hline & & & & & & & Holy shit! & 1 \\
\hline & & & & & & & Bloody hell! (BrE) & 1 \\
\hline & & & & & & 13. & Other exclamations & \\
\hline & & & & & & & No way! & 1 \\
\hline & & & & & & & Are you kidding me? & 2 \\
\hline & & & & & & & You can't be serious! & 1 \\
\hline & & & & & & & Wow! & 1 \\
\hline & & & & & & 14. & Could you curse in English < & \\
\hline & & & & & & & For sure, even strong explet & 6 \\
\hline & & & & & & & I think so & 4 \\
\hline & & & & & & & No & 1 \\
\hline
\end{tabular}

tables 


\begin{tabular}{|c|c|c|c|c|c|c|c|c|}
\hline Code no. & Politeness 1 & No. of students & Code no. & Politeness 2 & No. of students & Code no. & Idiomatic expressions & No. of students \\
\hline \multirow[t]{7}{*}{15.} & Using elements of politeness & & 17. & Appropriate use of please & & 21. & Idioms right away & \\
\hline & Avoiding direct orders by using modals & 10 & & Appropriate & 39 & & To feel under the weather & 2 \\
\hline & Be so kind to.. & 4 & & Inappropriate & 1 & & To break a leg & 2 \\
\hline & Mind to.. & 1 & 18. & Expressing regret & & & To rain cats and dogs & 2 \\
\hline & Excuse me.. & 2 & & I'm (so) sorry & 6 & & To be on top of the world & 2 \\
\hline & Greetings & 2 & & I'm sorry for you & 2 & & To have butterflies in one's stomach & 1 \\
\hline & Adressing appropriately & 4 & & I'm sorry about that & 2 & & To talk to someone later & 1 \\
\hline \multirow[t]{24}{*}{16.} & Recognising rude phrases & & $19 .$. & Accracting attention & & & To lose a train of thought & 1 \\
\hline & Get lost! & & & Excuse me! & 6 & & Till next time! & 1 \\
\hline & Impolite & 10 & & Pardon! & 2 & 22. & Other common idioms & \\
\hline & polite & 0 & & $\mathrm{X}$ & 2 & & To feel under the weather & \\
\hline & neutral & 0 & 20. & Apologizing for minor offence & & & Appropriate & 10 \\
\hline & Suit yourself! & & & Excuse me! & 7 & & Inapropriate/X & 0 \\
\hline & Impolite & 1 & & Pardon! & 1 & & To be a fair weather friend & \\
\hline & polite & 4 & & $\mathrm{X}$ & 2 & & Appropriate & 0 \\
\hline & neutral & 5 & & & & & Inappropriate/X & 10 \\
\hline & Be my guest! & & & & & & To break a leg & \\
\hline & impolite & 0 & & & & & Appropriate & 3 \\
\hline & polite & 8 & & & & & Inappropriate/X & 7 \\
\hline & neutral & 2 & & & & & To pull one's leg & \\
\hline & Who asked you? & & & & & & Appropriate & 2 \\
\hline & impolite & 6 & & & & & Inappropriate/X & 8 \\
\hline & polite & 3 & & & & & To speak of the devil & \\
\hline & neutral & 1 & & & & & Appropriate & 3 \\
\hline & & & & & & & Inappropriate/X & 7 \\
\hline & & & & & & & To keep fingers crossed & \\
\hline & & & & & & & Appropriate & 7 \\
\hline & & & & & & & Inappropriate/X & 3 \\
\hline & & & & & & & To touch wood & \\
\hline & & & & & & & Appropriate & 5 \\
\hline & & & & & & & Inappropriate/X & 5 \\
\hline
\end{tabular}




\begin{tabular}{|c|c|c|c|c|c|c|c|c|}
\hline Code no. & Accents and dialects & No. of students & Code no. & & & Code no. & Background information & No. of students \\
\hline \multirow{12}{*}{23.} & Recognising familiar accents and dialects & & 25. & Colloquialisms, slangs and dialectisms & No. of students & 26. & Frequency of using english outside school & \\
\hline & British English and varieties & 10 & & Common in American English & & & Never & 2 \\
\hline & American English and varieties & 10 & & What's up & 5 & & Once a week & 1 \\
\hline & Australian English & 9 & & Howdy & 2 & & 3 times a week & 2 \\
\hline & Regional accents British English & & & Dawg & 2 & & every day & 5 \\
\hline & Scottish English & 2 & & Bro & 4 & 27. & English through multimedia & \\
\hline & Irish English & 2 & & Lad & 2 & & Netflix & 7 \\
\hline & Welsh English & 1 & & Holy moly! & 1 & & Other streaming platforms & 5 \\
\hline & Yorkshire English & 1 & & ma'am & 1 & & Youtube & 7 \\
\hline & Regional accents American English & & & Common in British English & & & Video games & 6 \\
\hline & Afro-american English & 1 & & mate & 4 & & Podcasts & 4 \\
\hline & Southern American English & 2 & & lad & 2 & & Music & 10 \\
\hline \multirow[t]{15}{*}{24.} & Problematic accents & & & honey & 2 & & News & 1 \\
\hline & British English (general) & 4 & & bickies & 1 & & English TV channels & 1 \\
\hline & American English (general) & 1 & & Common in Australian English & -1 & & Social networking & 10 \\
\hline & Scottish English & 2 & & Thongs & 1 & & Books & 2 \\
\hline & Irish English & 1 & & Barbie & 1 & 28. & English lessons outside school & \\
\hline & Welsh English & 1 & & Bloody hell! & 1 & & $\mathrm{X}$ & 7 \\
\hline & Indian non-native accent & 1 & & Mate & 4 & & 2 hours a week & 3 \\
\hline & & & & Aussie & 1 & 29. & Major development of ICC & \\
\hline & & & & General & & & Watching films/tv series & 3 \\
\hline & & & & informal contractions & 8 & & Lessons outside classroom & 3 \\
\hline & & & & Barbie & 1 & & Youtube & 2 \\
\hline & & & & Bloody hell! & 1 & & School lessons & 1 \\
\hline & & & & Mate & 4 & & Music & 1 \\
\hline & & & & Aussie & 1 & & & \\
\hline & & & & Thongs & 1 & & & \\
\hline
\end{tabular}

